\title{
The Chemical Composition of New Hebridean Human Milk
}

\author{
By F. E. PETERS \\ South Pacific Commission, Noumea, New Caledonia
}

(Received 8 September 1952)

The peoples of the New Hebrides, like those of most Pacific areas, do not wean their infants until a relatively late age. It is common to see children of $18-24$ months still suckling, and the normal procedure is to wean the child between 12 and 24 months of age, unless another pregnancy intervenes, when the child is weaned immediately.

The reason for this late weaning appears to be nutritional, as there is a lack of suitable weaning foods. However, from a very early age the children have food, such as pre-masticated taro, placed in their mouths. It is hard to fix a definite time when suckling ceases altogether for, as Hipsley (1947, p. r03) points out, toddlers up to perhaps 3 years of age are allowed to suckle if they become fretful.

It was decided to determine the composition of New Hebridean native breast milk as an adjunct to the work in these Islands of the South Pacific Commission's Nutritionist, and also to try to determine $(a)$ whether there were any marked differences between the proportions of milk constituents of European and Melanesian women and $(b)$ whether there were any changes in the constituents during the later lactation periods.

\section{Collection of samples}

METHODS

The milk was collected from lactating mothers in the Port Vila area of the New Hebrides. As it is the local practice to allow the infant to suckle whenever he feels inclined, and as $24 \mathrm{~h}$ samples would be almost impossible to obtain from 'bush' peoples, $4 \mathrm{~h}$ samples were taken by a standardized technique of collection.

The recommended method of collection was as follows: $(a)$ empty both breasts completely, (b) allow no feeding for $4 \mathrm{~h},(c)$ collect all the milk from both breasts at the end of the $4 \mathrm{~h}$ period, using a breast pump, $(d)$ measure and record the quantity collected, $(e)$ agitate thoroughly and take a sample of at least $60 \mathrm{ml}$. if possible, $(f)$ label and seal the containers.

Difficulty was sometimes experienced in preventing feeding during the $4 \mathrm{~h}$ period, and this is reflected in the variations in the fat content of the samples.

The samples were sent by air to Canberra, a journey occupying 2 days. To prevent deterioration, from four to five drops of $40 \%$ aqueous formaldehyde were added to each $60 \mathrm{ml}$. bottle, and the bottles were made light-proof by coating the outsides with black Dulux paint. On their arrival in Canberra the samples were placed in a refrigerator. No samples showed any signs of souring or ropiness.

In all, fifty-four samples were collected, but one was lost in transit and two were too meagre to use, so that the results presented are for fifty-one samples. 
'Control' group

Seven milk samples were obtained from Canberra women and were analysed concurrently with the New Hebridean milks. The ages of the infants in this 'control' group ranged from 2 to 7 months.

\section{Chemical analysis}

The analyses were carried out at the Australian Institute of Anatomy, Canberra, Australia.

Each sample was examined for fat, lactose, ash, protein, calcium and phosphorus. The methods used for these analyses were:

Fat. The fat content was determined by the Röse-Gottlieb method of the Association of Official Agricultural Chemists (1940, p. 272).

Lactose. The lactose was determined by a modification of the Somogyi (r945) method for blood glucose. To $0.5 \mathrm{ml}$. milk were added $0.5 \mathrm{ml}$. $10 \%$ (w/v) $\mathrm{ZnSO}_{4} \cdot 7 \mathrm{H}_{2} \mathrm{O}$, $0.5 \mathrm{ml} .0 .5 \mathrm{~N}-\mathrm{NaOH}$ and $3.5 \mathrm{ml}$. water. The precipitate formed was filtered off and 0.1 and $0.2 \mathrm{ml}$. filtrate (measured with a standard capillary pipette) were each diluted to $5 \mathrm{ml}$. with water, and $5 \mathrm{ml}$. of the Somogyi copper solution were added. The solutions were kept in boiling water for 25 min., cooled to $35^{-}-40^{\circ}$, acidified with I ml. $5 \mathrm{~N}^{-\mathrm{H}_{2}} \mathrm{SO}_{4}$ and titrated against $0.005 \mathrm{~N}-\mathrm{Na}_{2} \mathrm{~S}_{2} \mathrm{O}_{3}$, starch indicator being used. A curve was constructed from known quantities of lactose monohydrate, and the amount of anhydrous lactose in the milk sample was calculated by means of this curve.

Protein. The total nitrogen content of the milk was determined by Conway's (1947) microdiffusion technique. The total nitrogen figure was multiplied by 6.38 to give the percentage protein.

$A s h$. The amount of ash was determined by the direct weighing of the residue left after 1o $\mathrm{ml}$. milk had been ignited to $60^{\circ}$ for $2 \mathrm{~h}$.

Calcium and phosphorus. These elements were estimated by the methods of Winikoff (1944).

\section{RESULTS}

The samples examined were obtained from women whose lactation periods ranged from 2 to 24 months. In order to determine whether there are any gross changes in the composition of the milk during lactation, the samples were divided into three groups, 2nd-5th months (containing eighteen samples), 6th-I Ith months (containing fifteen samples) and I 2 th-24th months (containing eighteen samples).

The results are set out in Table $\mathrm{I}$. This table shows the mean value, standard error of the mean and range for the constituents examined in each group and also for the total number of samples. A comparison is made with the results for the milk from the seven Canberra women and with results previously published for milk from American women (Macy, 1949).

\section{DISCUSSION}

Statistical analysis of the results indicated that there was a significant decline in ash and protein with time, and that during the period of lactation, 2-24 months, there was no evidence of curvature in any of the graphs for this trend. The regressions of lactose, 
calcium and phosphorus on time appeared negative but were not statistically significant.

The ratios of the regression coefficients to their respective means were taken in pairs and the differences tested for significance. The ratios did not differ significantly, and this suggests that a falling off in the non-fatty solids takes place with time, the ratio of the constituents to one another remaining constant.

It will be seen from Table I that the lactose, calcium and ash figures were low, although they fell within the range of published values.

'Table I. Mean values for the major constituents of New Hebridean human milk, compared with those for Canberra human milk, and with those previously published (Macy, 1949) for American human milk

\begin{tabular}{|c|c|c|c|c|c|c|c|}
\hline $\begin{array}{c}\text { Lactation } \\
\text { period } \\
\text { (months) }\end{array}$ & $\begin{array}{l}\text { No. of } \\
\text { samples }\end{array}$ & $\begin{array}{c}\text { Lactose* } \\
\text { (g/100 ml.) }\end{array}$ & $\begin{array}{l}\text { Protein* } \\
\text { (g/10o ml.) }\end{array}$ & $\begin{array}{c}\text { Fat" } \\
\text { (g/100 ml.) }\end{array}$ & $\begin{array}{c}\text { Ash" } \\
(\mathrm{mg} / \mathrm{r} 00 \mathrm{ml} .)\end{array}$ & $\begin{array}{c}\text { Calcium* } \\
\text { (mg/roo ml.) }\end{array}$ & $\begin{array}{l}\text { Phosphorus* } \\
\text { (mg/100 ml.) }\end{array}$ \\
\hline \multicolumn{8}{|c|}{ Values for New Hebridean human milk } \\
\hline $2-5$ & I 8 & $\begin{array}{c}5.05 \pm 0.11 \\
(4.2-5.8)\end{array}$ & $\begin{array}{l}1 \cdot 49 \pm 0.14 \\
(I \cdot 09-I \cdot 7 I)\end{array}$ & $\begin{array}{l}3.8 \pm 0.4 \\
(I .8-6 \cdot 4)\end{array}$ & $\begin{array}{c}188 \pm 3 \\
(170-210)\end{array}$ & $\begin{array}{c}27 \cdot 4 \pm 1 \cdot 0 \\
(20 \cdot 8-34 \cdot 0)\end{array}$ & $\begin{array}{c}15 \cdot 9 \pm 0.4 \\
(13-18)\end{array}$ \\
\hline $6-11$ & 15 & $\begin{array}{c}5.00 \pm 0.13 \\
(4.4-6 \cdot 0)\end{array}$ & $\begin{array}{l}I \cdot 39 \pm 0 \cdot 14 \\
(I \cdot 10-1 \cdot 6 I)\end{array}$ & $\begin{array}{l}3 \cdot 8 \pm 0.4 \\
(1 \cdot 8-6 \cdot 0)\end{array}$ & $\begin{array}{c}178 \pm 3 \\
(165-205)\end{array}$ & $\begin{array}{c}25 \cdot 1 \pm 1 \cdot 3 \\
(19 \cdot 2-34 \cdot 0)\end{array}$ & $\begin{array}{c}15.1 \pm 0.6 \\
(12-19)\end{array}$ \\
\hline $12-24$ & 18 & $\begin{array}{c}4.91 \pm 0.11 \\
(4.1-5 \cdot 4)\end{array}$ & $\begin{array}{l}I \cdot 33 \pm 0 \cdot I I \\
(I \cdot 03-I \cdot 57)\end{array}$ & $\begin{array}{l}3 \cdot 8 \pm 0 \cdot 3 \\
(2 \cdot 0-6 \cdot 2)\end{array}$ & $\begin{array}{c}176 \pm 4 \\
\left(155^{-2} 10\right)\end{array}$ & $\begin{array}{c}24.9 \pm 1.2 \\
(18.6-33.8)\end{array}$ & $\begin{array}{c}14.7 \pm 0.5 \\
\text { (1 } 2-19)\end{array}$ \\
\hline $2-24$ & 51 & $\begin{array}{c}5.00 \pm 0.06 \\
(4.1-6.0)\end{array}$ & $\begin{array}{l}I \cdot 40 \pm 0.08 \\
(I \cdot 03-I \cdot 7 I)\end{array}$ & $\begin{array}{l}3 \cdot 8 \pm 0 \cdot 2 \\
(1 \cdot 8-6 \cdot 4)\end{array}$ & $\begin{array}{c}181 \pm 2 \\
(155-210)\end{array}$ & $\begin{array}{c}25.8 \pm 0.7 \\
(18 \cdot 6-34 \cdot 0)\end{array}$ & $\begin{array}{c}15 \cdot 2 \pm 0 \cdot 3 \\
(12-19)\end{array}$ \\
\hline \multicolumn{8}{|c|}{ Values for Canberra human milk } \\
\hline $2-7$ & 7 & $\begin{array}{c}6.35 \pm 0.57 \\
(5 \cdot 2-7 \cdot 4)\end{array}$ & $\begin{array}{l}1 \cdot 22 \pm 0 \cdot 15 \\
(I \cdot 05-1 \cdot 41)\end{array}$ & $\begin{array}{l}4 \cdot 1 \pm 0 \cdot 6 \\
(2 \cdot 6-7 \cdot 1)\end{array}$ & $\begin{array}{c}219 \pm 5 \\
(210-240)\end{array}$ & $\begin{array}{c}3 I \cdot I \pm I \cdot 2 \\
(26 \cdot 5-34 \cdot 5)\end{array}$ & $\begin{array}{c}15.6 \pm 0.7 \\
\left(13^{-18}\right)\end{array}$ \\
\hline \multicolumn{8}{|c|}{ Values previously published (Macy, 1949) for American human milk } \\
\hline Mature & - & $\begin{array}{c}7 \cdot 1 \\
(4 \cdot 9-9 \cdot 5)\end{array}$ & $\begin{array}{c}1.06 \\
(0.73-2.00)\end{array}$ & $\begin{array}{c}4 \cdot 5 \\
(x \cdot 3-8 \cdot 3)\end{array}$ & $(160-266)$ & $\begin{array}{c}34 \cdot 4 \\
(17 \cdot 3-60 \cdot 9)\end{array}$ & $\begin{array}{c}14 \cdot I \\
(6 \cdot 8-26 \cdot 8)\end{array}$ \\
\hline
\end{tabular}

* Mean value with its standard error; figures in parentheses give the mean range.

Macy, Kelly \& Sloan (1950) have stated that approximately I7\% of the total nitrogen in human milk represents non-protein nitrogen. Therefore, if the total nitrogen value was multiplied by a factor 5.2 instead of 6.38 , a value more nearly representing the protein content of the milk would result. If the mean total nitrogen value for the 2-24 months New Hebridean milk samples were multiplied by $5.2 \mathrm{a}$ mean value of $1 \cdot 12 \pm 0.02 \mathrm{~g} / \mathrm{r} 00 \mathrm{ml}$. would be obtained. This value is in closer agreement with Macy's (1949) value of $1.06 \mathrm{~g} / 100 \mathrm{ml}$. than is the value of $1.40 \pm$ $0.08 \mathrm{~g} / \mathrm{r} 00 \mathrm{ml}$. quoted in the table. Macy's (1949) value was obtained by multiplying the value for protein nitrogen by the factor 6.37 , a method that eliminated the nonprotein nitrogen fraction and should give a true protein value.

The fat content varied over an extremely wide range. This is probably due in the main to a lack of co-operation on the part of the native mothers. It is known that 'strippings' are high in fat so that milk that has not been fully 'stripped' will have a lowered fat content. 
Although there appear to be some differences between the milk of Melanesians and that of Europeans and Americans, insufficient results are available for valid conclusions to be made as to the reality of these differences. For this many more samples would have to be obtained, and a standard technique of collection would have to be rigidly followed. It would appear, however, that Melanesian milk may be lower in lactose and calcium than European and American milk.

The decline in constituents with the length of the lactation period followed a trend already observed by other workers. Whether this trend was real cannot be determined from the number of results obtained.

\section{SUMMARY}

I. Fifty-one samples of human milk from Melanesian natives of the New Hebrides and seven samples of European milk from Canberra were analysed for lactose, fat, protein, ash, calcium and phosphorus.

2. It would appear that Melanesian human milk may have lower lactose and calcium content than European human milk.

3. There was a slight decline in the non-fatty constituents over the lactation period 2-24 months.

I wish to thank Miss S. Malcolm, of the South Pacific Commission, for the collection of samples, Dr A. J. Metcalfe and Dr E. H. Hipsley, of the Commonwealth Department of Health, for making available to me the facilities of the Australian Institute of Anatomy and Mr G. A. McIntyre, Senior Statistician, Commonwealth Scientific and Industrial Research Organization, Canberra, for carrying out a statistical analysis of the results.

\section{REFERENCES}

Association of Official Agricultural Chemists (1940). Official and Tentative Methods of Analysis of the Association of Official Agricultural Chemists, $5^{\text {th }}$ ed. Washington: Association of Official Agricultural Chemists.

Conway, E. J. (1947). Microdiffusion Analysis and Volumetric Error, and ed. London: Crosby Lockwood.

Hipsley, E. H. (1947). Report of the New Guinea Nutrition Survey Expedition. Canberra: Department of External Territories.

Macy, I. G. (1949). Amer. F. Dis. Child. 78, 589.

Macy, I. G., Kelley, H. \& Sloan, R. (1950). Bull. nat. Res. Coun., Wash., no. I I9.

Somogyi, M. (1945). F. biol. Chem. 160,61.

Winikoff, O. (1944). Med. F. Aust. 31, 660. 